\title{
KANDUNGAN LOGAM BERAT KADMIUM (Cd) DAN TIMBAL (Pb) PADA AIR DAN SEDIMEN KOLAM TANAH DI LOKA RISET BUDIDAYA IKAN HIAS AIR TAWAR, DEPOK
}

\author{
Ahmad Musa \\ Loka Riset Budidaya Ikan Hias Air Tawar \\ Jl. Perikanan No. 13, Pancoran Mas, Depok 16436 \\ E-mail : ahmadmusasaid@ yahoo.co.id
}

\begin{abstract}
ABSTRAK
Pencemaran di daerah perkotaan merupakan efek dari meningkatnya industri, aktivitas penduduk, dan faktor penyebab lainnya. Logam berat merupakan salah satu pencemar yang dapat membahayakan lingkungan. Kolam-kolam budidaya yang terdapat pada daerah perkotaan dikhawatirkan telah tercemari oleh logam berat. Pengamatan kandungan logam berat Kadmium (Cd) dan Timbal $(\mathrm{Pb})$ pada air dan sedimen di kolam tanah Loka Riset Budidaya Ikan Hias Air Tawar (LRBIHAT) didapatkan bahwa kolam tersebut telah tercemari oleh $\mathrm{Cd}$ dan $\mathrm{Pb}$. Hal ini terlihat dari kandungan $\mathrm{Cd}$ dalam sedimen dan $\mathrm{Pb}$ dalam air di kolam tersebut yang telah melewati baku mutu yang ditetapkan. Perlu dilakukan upaya penanggulangan terhadap kondisi lingkungan ini, serta pengamatan terhadap efek akumulasi logam $\mathrm{Cd}$ dan $\mathrm{Pb}$ pada kulit maupun jaringan tubuh ikan hias yang dibudidayakan di kolam tersebut perlu dilakukan.
\end{abstract}

KATAKUNCl: kadmium, timbal, air, sedimen, kolam tanah

\section{PENDAHULUAN}

Akuakultur atau budidaya perairan merupakan usaha pembudidayaan komersial organisme di dalam lingkungan akuatik air tawar, laut atau muara/kuala (Sudradjat, 2006). Tempat yang umum digunakan untuk budidaya misalnya kolam tanah, kolam beton, akuarium maupun karamba. Salah satu faktor yang penting untuk diperhatikan dalam budidaya adalah lingkungan, lingkungan sangat menentukan cepat atau lambatnya pertumbuhan bahkan tinggi atau rendahnya angka kematian ikan. Kandungan logam berat dalam air dan sedimen yang menumpuk dapat masuk ke rantai makanan, yang ujungnya akan membahayakan bagi manusia yang memakannya. Logam berat merupakan logam yang mempunyai densitas sama dengan atau lebih besar dari $5 \mathrm{~g} / \mathrm{cm}^{3}$ (Saeni dalam Diannanjaya, 1989). Kandungan logam berat dalam suatu lingkungan juga dapat menjadi parameter apakah lingkungan tersebut sudah tercemari atau masih aman.

Di antara logam berat yang memiliki efek yang berbahaya apabila terserap ke dalam tubuh makhluk hidup ialah Kadmium (Cd) dan Timbal (Pb). Pengamatan untuk mengetahui kandungan logam berat Kadmium (Cd) dan Timbal (Pb) dalam air dan sedimen pada kolam tanah di LRBIHAT, Depok bermanfaat untuk mendapatkan informasi mengenai kondisi pencemaran lingkungan pada daerah perkotaan khususnya kolam yang digunakan untuk budidaya pada LRBIHAT, Depok. Tujuan dari penelitian ini untuk mengetahui kandungan logam berat Kadmium (Cd) dan Timbal (Pb) yang terdapat pada air dan sedimen kolam tanah di LRBIHAT, Depok.

Pengamatan berlangsung selama 6 pekan dengan cara pengambilan sampel air dan sedimen yang dilakukan pada pukul 15.00 WIB sebanyak 4 kali (Tabel 1).

Tabel 1. Jadwal pengambilan sampel air dan sedimen

\begin{tabular}{cc}
\hline Sampling ke - & Tanggal \\
\hline I & 22 September 2008 \\
II & 6 Oktober 2008 \\
III & 20 Oktober 2008 \\
IV & 3 November 2008 \\
\hline
\end{tabular}

Sampel air diambil pada tiga tempat yaitu kolam I, II, dan III (Gambar 1) dengan menggunakan botol sampel 500 miliLiter $(\mathrm{mL})$, untuk sedimen diambil dari rongga pipa paralon yang ditancapkan 25 centimeter $(\mathrm{cm}) \mathrm{ke}$ dalam tanah.

Pengukuran kandungan logam berat $\mathrm{Cd}$ dan $\mathrm{Pb}$ dilakukan dengan menggunakan Spektrofotometer Serapan Atom tipe "Smart Spectro". Data yang diperoleh kemudian dianalisis menggunakan software "Microsoft Office Excel 2003" dan "SPSS Statistic 17.0". 


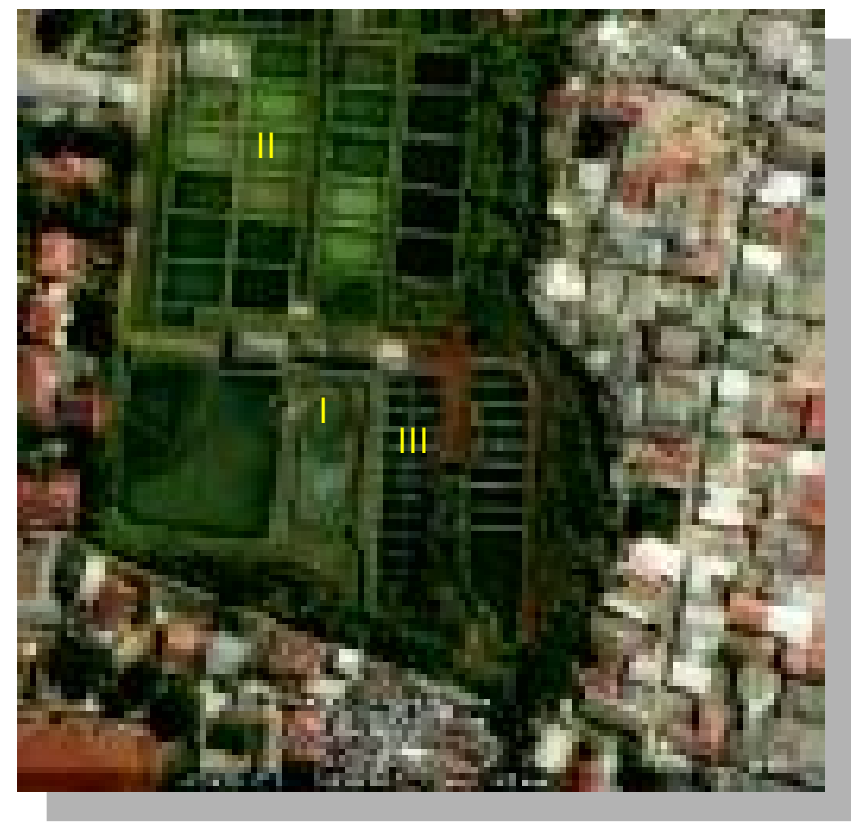

Gambar 1. Denah tempat pengambilan sampel air dan sedimen (www.googleearth.com)

\section{KONSENTRASI LOGAM KADMIUM (Cd)}

Dalam 6 pekan pengamatan, konsentrasi logam Kadmium (Cd) pada air tidak terdeteksi. Hal ini dapat disebabkan karena konsentrasi $\mathrm{Cd}$ dalam air tidak berada dalam batas deteksi alat yang digunakan atau sampel tersebut sudah rusak sehingga tak dapat dideteksi.

Konsentrasi logam Cd dalam sedimen pada kolam I meningkat dari sampling awal ke sampling kedua, namun terjadi penurunan pada sampling ketiga dan meningkat lagi pada sampling terakhir. Pada kolam II mengalami penurunan dari sampling pertama hingga ketiga namun meningkat pada yang terakhir. Adapun pada kolam ke III, terlihat peningkatan yang terus menerus dari sampling awal hingga akhir (Gambar 2).

Konsentrasi Cd pada tiap kolam berbeda setiap kali sampling, untuk sampling pertama dan keempat tertinggi pada kolam II sedang sampling kedua dan ketiga tertinggi pada kolam I. Namun secara rata-rata, berdasarkan hasil olahan statistik, kandungan Cd dalam sedimen pada ketiga kolam tersebut tidak berbeda nyata (Gambar 3).

Dari setiap kolam, kisaran konsentrasi Cd dalam sedimen adalah 10,16 $\pm 2,28 \mathrm{mg} / \mathrm{kg}$. Konsentrasi ini sudah melewati nilai batas ambang yang mungkin menimbulkan efek yaitu lebih dari 8,6 mg/kg (Febris \& Werner, 1994). Hal ini berarti bahwa konsentrasi Cd tersebut sudah dapat berbahaya bagi makhluk hidup. Logam Cd ini kemungkinan berasal dari air yang mengalir ke kolam dan masuk sebagai cemaran akibat aktivitas penduduk di sekitar tempat itu,

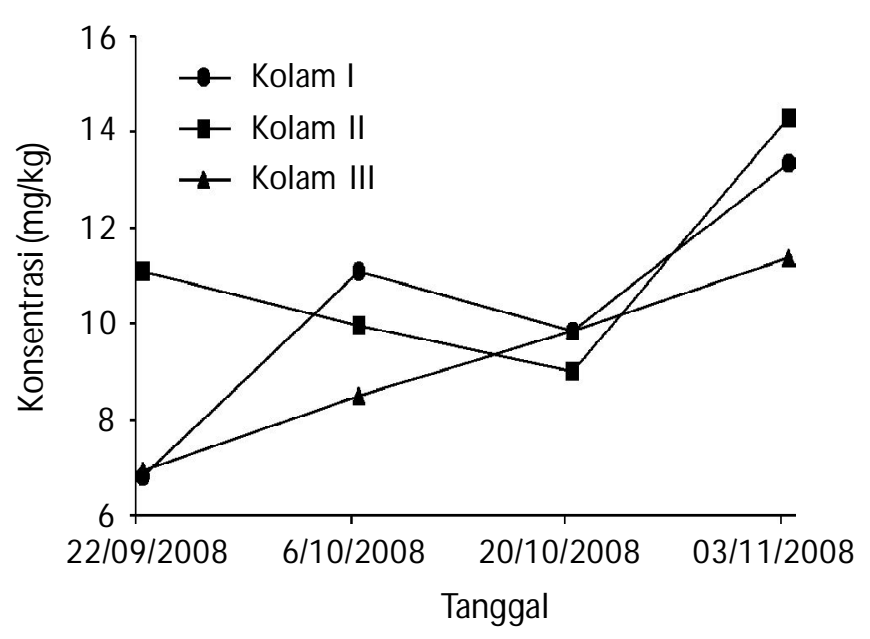

Gambar 2. Konsentrasi logam Cd dalam sedimen dari awal hingga akhir pengamatan selama 6 pekan, pada 3 kolam tanah di LRBIHAT, Depok

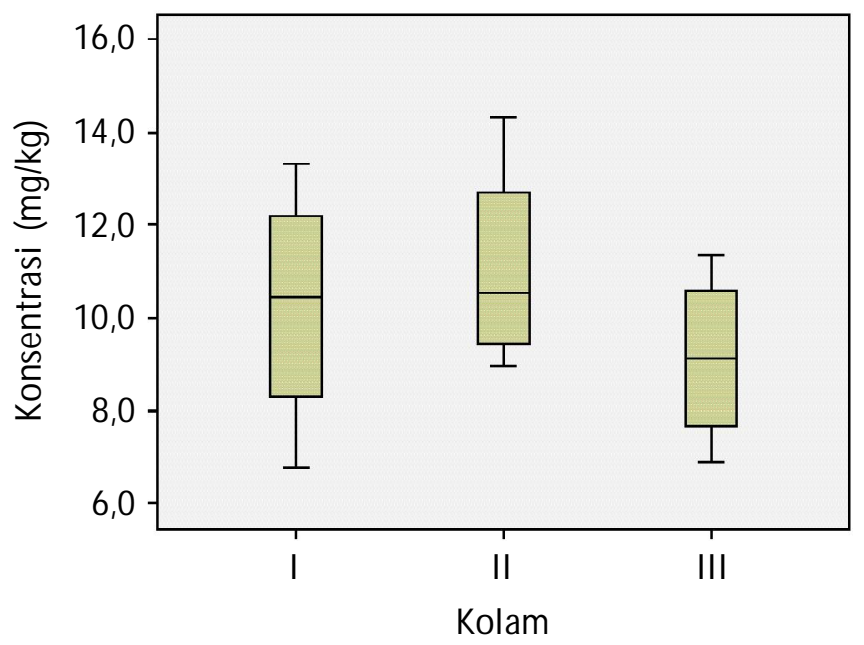

Gambar 3. Konsentrasi rata-rata logam Cd dalam sedimen dari 3 kolam di LRBIHAT, Depok

misalnya akibat pembakaran sampah, atau dapat pula dari buangan penduduk setempat seperti baterai-baterai bekas, sampah plastik, dan bahan-bahan yang mengandung zat pewarna yang merupakan salah satu sumber terbesar dari logam kadmium yang kemudian mengendap (Palar, 1994). Di samping itu, tidak tertutup kemungkinan berasal dari limbah industri yang terdapat di sekitar Kota Depok misalnya industri tegel/keramik, pengelasan logam maupun pipa air (Achmad, 2004).

Tingginya konsentrasi $\mathrm{Cd}$ dalam sedimen ini dapat memberikan efek mematikan bagi ikan yang dipelihara dalam kolam tersebut. Dan jika yang dipelihara adalah ikan konsumsi maka akan sangat membahayakan bagi manusia yang memakannya. Efek logam ini pada manusia ialah iritasi lokal, manifestasi kliniknya berupa mual-mual, 
muntah-muntah dan nyeri perut. Setelah penghirupan, efek yang ditimbulkan antara lain adalah edema paru-paru dan pneomonitis kimia.

Kadmium diekskresikan sangat lambat dengan waktu paruh 30 tahun. Apabila lama terakumulasi kerusakan terjadi dalam sistem fisiologi tubuh, di antaranya kerusakan ginjal (tempat kerja utamanya adalah tubulus proksimal). Kerusakan pada tubulus ini biasanya terjadi bila kadar Cd dalam ginjal mencapai $200 \mu \mathrm{g} / \mathrm{g}$ (kadar kritisnya). Kadmium juga menyebabkan penyakit osteomalaysia (berubahnya metabolisme tulang) dan juga menyebabkan karsinoma prostat. Sistem-sistem tubuh lainnya yang dirusak oleh Cd yaitu sistem sirkulasi darah, kadmium oksida (CdO) menyebabkan penyakit anemia (kekurangan darah). Pada sistem reproduksi, Cd dapat mematikan sel-sel sperma laki-laki. Kadmium juga dapat mengakibatkan kerapuhan pada tulang (Palar,1994).

\section{KONSENTRASI LOGAM TIMBAL (Pb)}

Logam $\mathrm{Pb}$ dalam air pada tiap kolam dari awal hingga akhir pengamatan kisaran konsentrasinya $0,689 \pm 0,003$ $\mathrm{mg} / \mathrm{L}$. Pada sampling pertama dan kedua konsentrasi logam $\mathrm{Pb}$ tertinggi terdapat pada kolam II. Pada sampling ketiga konsentrasi Pb dalam air pada ketiga kolam memiliki nilai yang sama $(0,689 \mathrm{mg} / \mathrm{L})$, tetapi pada sampling terakhir pada kolam I adalah yang paling tinggi (Gambar 4).

Rata-rata konsentrasi Pb dalam air pada setiap kolam tidak berbeda nyata, namun pada kolam II tampak lebih tinggi dan pada kolam III paling rendah (Gambar 5).

Berdasarkan PP 82 Tahun 2001, konsentrasi logam Pb dalam air ini telah melampaui baku mutu air untuk pemeliharaan ikan air tawar (air Kelas III) yaitu lebih dari

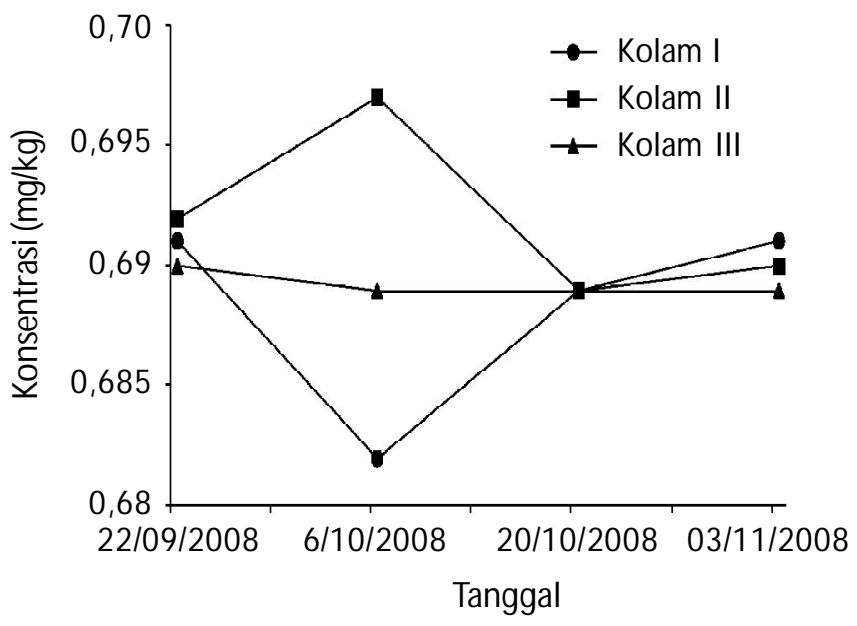

Gambar 4. Konsentrasi logam $\mathrm{Pb}$ dalam air dari awal hingga akhir pengamatan selama 6 pekan, pada 3 kolam tanah di LRBIHAT, Depok

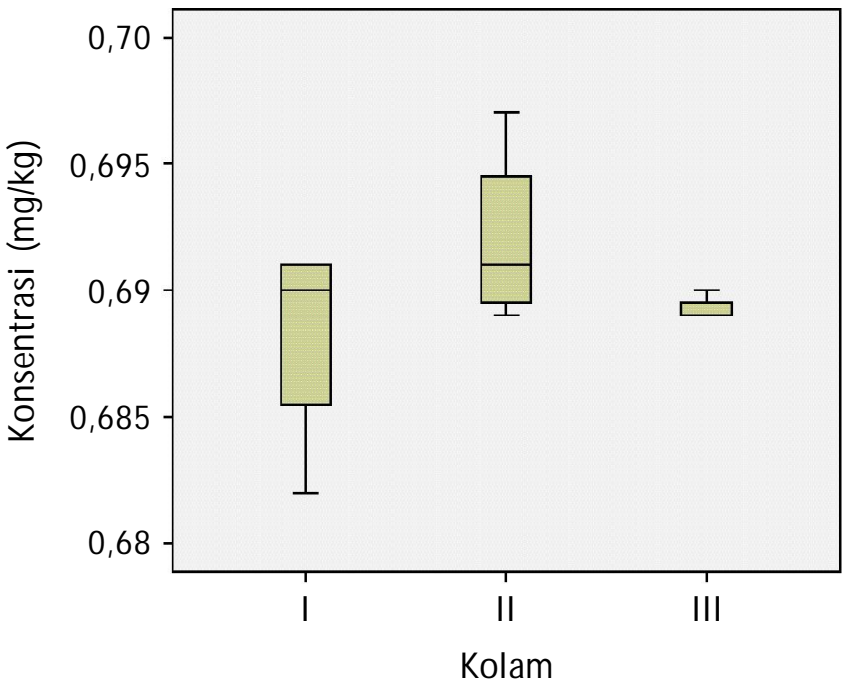

Gambar 5. Rata-rata konsentrasi logam Pb dalam air pada 3 kolam di LRBIHAT, Depok

0,03 mg/L. Dengan demikian ikan yang berada pada kolam ini bisa terancam teracuni. Bila ikan tersebut dimakan manusia maka timbal akan terakumulasi dalam jaringan tubuh sehingga berbahaya bagi kesehatan (Philips, 1993 dalam Nuhman, 2003), karena dapat menyebabkan anemia, kerusakan sistem saraf, ginjal, terganggunya sistem reproduksi, turunnya IQ dan berpengaruh terhadap penyerapan zat oleh tulang untuk pertumbuhan (Arifin, 2002), serta dapat merangsang kelahiran bayi prematur (Arisandi, 2004).

Pada sedimen kolam, kisaran konsentrasi Pb adalah $29,03 \pm 12,98 \mathrm{mg} / \mathrm{kg}$. Pada sampling pertama kolam II adalah yang paling tinggi, kemudian sampling kedua dan ketiga pada kolam I sedang, sampling terakhir konsentrasi tertinggi terdapat pada kolam III (Gambar 6).

Dari perhitungan nilai rata-rata $\mathrm{Pb}$ dalam sedimen paling tinggi adalah di kolam I dan terendah pada kolam III (Gambar 7).

Nilai ini belum melewati batas ambang yang dapat menimbulkan efek terhadap makhluk hidup yaitu 170 mg/kg (Febris \& Werner, 1994). Dengan demikian, dapat dinyatakan, kolam ini masih aman. Jika dibandingkan dengan kandungan $\mathrm{Pb}$ dalam air yang telah melewati baku mutu yang ditetapkan, hal ini menunjukkan bahwa masih ada harapan untuk melakukan pencegahan bertambahnya endapan logam Pb ke dalam sedimen.

Apabila dibandingkan adanya logam $\mathrm{Cd}$ dan $\mathrm{Pb}$ pada air dan sedimen di ketiga kolam, terlihat bahwa nilai ratarata paling kecil terdapat pada kolam III. Di mana air yang memasuki kolam III ini sebelumnya melalui kolam filter yang ditumbuhi enceng gondok (Eichornia crassipes). Telah 


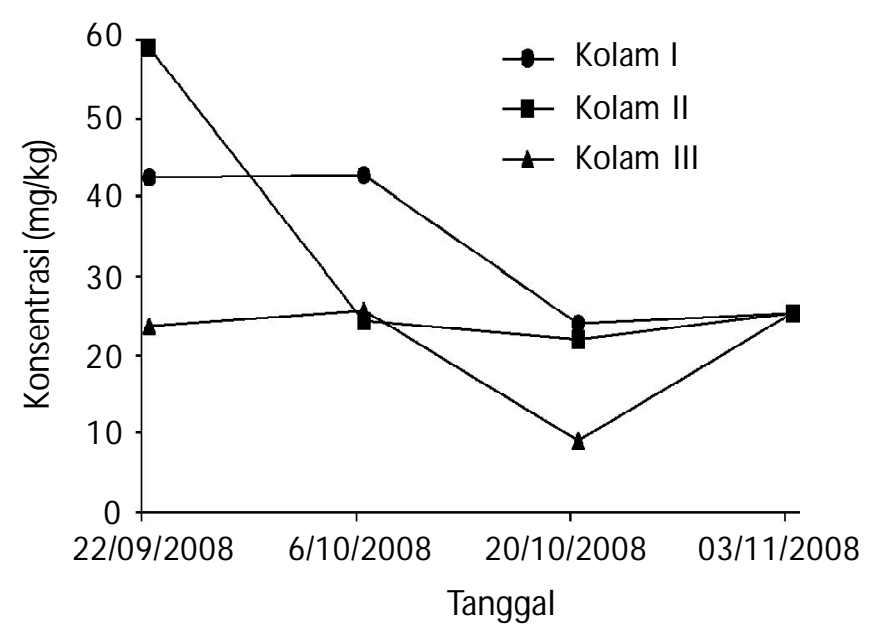

Gambar 6. Konsentrasi logam $\mathrm{Pb}$ dalam sedimen dari awal hingga akhir pengamatan selama 6 pekan, pada 3 kolam tanah di LRBIHAT, Depok

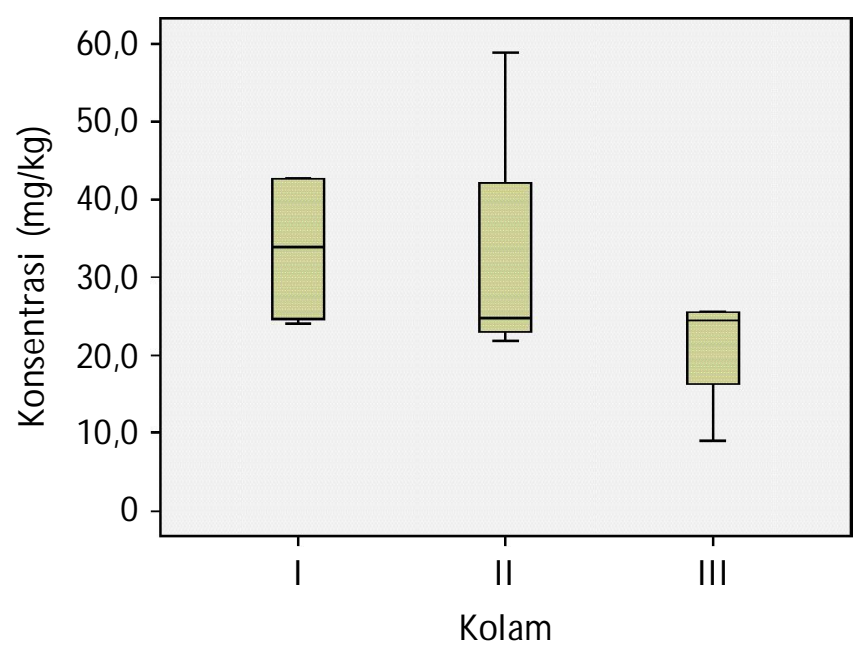

Gambar 7. Konsentrasi rata-rata logam Pb dalam sedimen pada 3 kolam di LRBIHAT, Depok

diketahui bahwa enceng gondok dapat menjadi filter logam berat dalam air (Little, 1979).

Mengingat konsentrasi logam $\mathrm{Cd}$ dan $\mathrm{Pb}$ dalam kolam yang diamati telah melewati baku mutu, maka penggunaannya untuk budidaya ikan hias sudah cukup tepat. Karena apabila digunakan untuk budidaya ikan konsumsi dapat menimbulkan risiko pada manusia yang mengkonsumsinya apalagi jika terjadi terus-menerus.

\section{KESIMPULAN DAN SARAN}

Kolam tanah di Loka Riset Budidaya Ikan Hias Air Tawar (LRBIHAT) Depok telah tercemari oleh logam berat Kadmium ( $\mathrm{Cd}$ ) dan Timbal (Pb). Hal ini terlihat dari kandungan $\mathrm{Cd}$ dalam sedimen yaitu $10,16 \pm 2,28 \mathrm{mg} / \mathrm{kg}$ dan $\mathrm{Pb}$ dalam air yaitu $0,689 \pm 0,003 \mathrm{mg} / \mathrm{L}$. Konsentrasi ini telah melewati baku mutu yang ditetapkan yaitu 8,6 $\mathrm{mg} / \mathrm{kg}$ untuk Cd (Febris \& Werner, 1994) dan 0,689 0 0,003 $\mathrm{mg} / \mathrm{L}$ untuk Pb (PP 82 tahun 2001).

Upaya penanggulangan yang perlu dilakukan adalah pengerukan sedimen kolam dan filtrasi air yang masuk dengan menggunakan filter tanaman seperti enceng gondok. Perlu dilakukan pengamatan terhadap efek dan akumulasi logam $\mathrm{Cd}$ dan $\mathrm{Pb}$ yang mungkin terjadi pada kulit dan jaringan tubuh ikan hias yang dibudidayakan.

\section{DAFTAR ACUAN}

Achmad, R. 2004. Kimia Lingkungan. Penerbit ANDI. Yogyakarta, $171 \mathrm{hlm}$.

Arifin, Z. 2002. Pencemaran di Teluk Jakarta M emperhatinkan. Harian Suara Pembaharuan.

Arisandi, P. 2004. M ewaspadai Bahaya Timbal Di Surabaya. http://www.ecoton.or.id.

Diananjaya, I. 1989. Distribusi Logam Berat Cd, Cu, Pb \& Zn, dalam Sedimen Permukaan Laut Dangkal. Skripsi Jurusan Kimia FMIPA-UH, Makassar.

Febris,G.J. dan Werner,G.F. 1994. Characterization of Toxicants in Sedimen From Port Philip Bay, Metal Departemen of Conservation and Metal Resourcers Melbourne, Australia.

Little, E.C.S. 1979. Handbook of Utilization of Aquatic Plants. FAO, USA, $176 \mathrm{hlm}$.

Nuhman. 2003. Kandungan Kadmium pada Udang Windu (Penaeus monodon) Hasil Budidaya secara Intensif dan Tradisional. Majalah IImiah Kelautan: Neptunus, Universitas Hang Tuah Surabaya, Vol. 1 No. 1.

Palar, H. 1994. Pencemaran dan Toksikologi logam berat. Penerbit Rineka Cipta, Jakarta.

Sudradjat, A. 2006. Glosarium Kelautan dan Perikanan. Pusat Riset Perikanan Budidaya. Jakarta, hlm. 6. 